УДК $94(477.73)$ «19»

DOI: https://doi.org/10.33782/eminak2021.2(34).517

\title{
ДЖЕРЕЛА ПОПОВНЕННЯ КУПЕЦТВА МИКОЛАЄВА У ХІХ СТ.
}

\author{
Ганна Макушина \\ Одеська державна академія будівництва та архітектури (Одеса, Україна) \\ e-mail: annamakusina1981@gmail.com \\ ORCID: https://orcid.org/0000-0002-0106-9574
}

Стаття присвячена особливостям поповнення купецтва міста Миколаєва представниками інших станів під час формування та еволюції купецького стану міста протягом XIX ст. Особливу увагу приділено ролі міщан у формуванні купецтва Миколаєва та специфіці їх входження до стану. Визначено соціальний статус осіб, які переходили у миколаївське купецтво з інших міст Російської імперії.

Ключові слова: купещь, купецький син, міщани, Миколаӥвська міська дума, Миколаїв

У сучасній Україні важливу роль відіграє торгівельна діяльність. Отже, актуальним постає питання дослідження історії розвитку купецтва як носія торгівельних відносин Південної України. Взагалі купецтво є унікальним станом, який на перше місце ставило наявність капіталу, тобто готовність до активної торгівельної діяльності, а не соціальний статус. Тема поповнення купецького стану дає можливість з'ясувати питання: з яких соціальних станів потрапляли нові представники купецтва.

Тема джерел поповнення купецького стану Миколаєва не висвітлена у сучасній історіографії, проте українські дослідники приділяють увагу купецтву в своїх наукових працях, торкаючись деяких питань історії українського купецтва. Останнім часом з'явилась традиція дослідження купецького стану окремих регіонів України. Становище купецтва Київщини, Лівобережної та Слобідської України дослідив доктор історичних наук О. Гуржій ${ }^{1}$. Особливості розвитку купецтва окремих регіонів українських земель досліджували О.Донік та Т. Лазанська2. Т. Ігнатьєва вивчає особливості розвитку купецтва Правобережної України‥ Ю.Бєліков присвятив своє дослідження проблемам купецтва Харківської губернії4, А. Безшкуренко та Н. Салтанова - єлисаветградському купецтву5.

\footnotetext{
1 Гуржій О. Деякі проблеми становлення купецького стану в Україні. Київ: IIУ НАНУ, 2004; Гуржій О. Купецький стан на Лівобережній і Слобідській Україні в другій половині XVII - XVIII ст.: проблеми становлення та розвитку // Український історичний журнал. 2004. № 3. С. 3-21; Гуржій О., Гуржій I. Купецтво Києва та Київщини XVII - XIX ст. Київ: IIУ НАНУ, 2013.

2 Донік О. Купецтво України в імперському просторі (XIX ст.). Київ: IIУ НАНУ, 2008; Лазанська Т. Iсторія підприємництва в Україні (на матеріалах торгово-промислової статистики XIX ст.). Київ: IIУ НАНУ, 1999; Лазанська Т. Соціальне походження промислової буржуазії України в XIX ст. // Український історичний журнал. 1996. № 2. С. 65-73; Лазанська Т. Торговельні доми України на рубежі двох століть (1892-1914рр.) // Проблеми історії України XIX - початку XX ст. 2001. № 2. С. 24-41.

3 Ігнатьєва T. Купецтво правобережної України в кінці XVIII - першій половині XIX століття: соціально-етнічний аспект // Наукові праці Кам'янець-Подільського педагогічного університету: історичні науки. 2003. Вип. 11. С. 172-179.

4 Бєліков Ю. Купецтво Харківської губернії (друга половина XIX - початок XX ст.): Дис... к.і.н. Харків, 2003.

5 Безшкуренко А. Розвиток торгівлі в місті Єлисаветграді у другій половині XIX - на початку XX ст. // Збірник наукових праць $\Lambda^{\prime}$ ОГОГ. 2020. № 2. C. 131-132. DOI: 10.36074/26.06.2020.v2.49; Салта-
} 
Вчені В. Ковалинський, О. Марченко та Н. Салтанова, Ф. Шепель вивчають історію окремих купецьких родин 6 .

У сучасних наукових працях розкривається низка питань щодо благодійності купецтва. Виділимо праці Л. Даниленка, О. Доніка, В. Ковалинського7.

Метою статті $є$ дослідження особливостей поповнення купецтва міста Миколаєва протягом XIX ст.

Завдання даної статті полягають у вивченні особливостей входження осіб до купецького стану, поясненні причин переходу міщан у купецтво Миколаєва, висвітленні особливостей подання документів до органів міської влади з метою запису у купці, дослідження окремих випадків видачі паспортів.

Миколаїв розпочав свою історію з виникнення суднобудівної верфі, на яку з перших днів існування необхідно було постачати різноманітні продукти, будівельні матеріали та вироби, купецтво з'явилось тут ще до отримання Миколаєвом статусу міста. Воно було непостійним, неоднорідним і мало багато джерел походження, а згодом сформувалося та перетворилося на стан, який тримав у своїх руках торгівлю та підприємництво.

Статус купецтва регулювався іменними указами, указами Сенату, документацією Миколаївської міської думи та Миколаїської міської управи.

Одним з перших документів, який регламентував діяльність купецького стану в Миколаєві, була «Грамота на права та вигоди містам Російської імперії» від 21 квітня 1785 р. Вона надавала купцям певні пільги. Купці перших двох гільдій звільнялися від тілесних покарань, купці 1-ї гільдії мали право пересуватися у кареті та вести торгівлю за межами Російської імперії, а 2-ї гільдії - мати парокінну коляску8.

Згідно тогочасного законодавства представники купецтва, які на наступний рік прагнули перебувати у тому ж стані, подавали заяви на наявність капіталу в кінці кожного року. У Держархіві Миколаївської області зберігається багато подібних документів, проте виділимо заяви купців про поновлення на 1885 р. у 2-й гільдії: Р. Авраамова, Е. Берга, С. Вайсбейна, Б. Вуліха, І. Ерліха, К. Кобякова, М. Колеснікова, А. Міліо, О. Остринського, Г. Рапепорта, А. Стаканова, І. Фінкельштейна, Я. Шора. Родинні списки та заяви надали у 1885 р. на вступ до 2-ї гільдії Х. Бунцельман, М. Габіс, Є. Гончаров, Д. Шелейснович, І. Курчатов, І. Калегорський, I. Канєвський, М. Бланк, Л. Тімен ${ }^{9}$ та ін.

Особливе ставлення було у владних структур Російської імперії до єврейського населення. Євреї мали свій окремий статус, який регулював і відносини у купецькому стані. 20 листопада 1829 р. вийшов царський указ «Про заборону євреям, які не знаходяться на службі, мати постійне перебування в містах Миколаєві та Севас-

нова Н. Купечество Елисаветграда (исторические очерки). Кировоград: КИРаЧ Украина, 2011.

${ }^{6}$ Ковалинский В. Семья Терещенка. Киев: Пресса Украины, 2003; Марченко О., Салтанова Н. Особливості розвитку купецтва в Єлисаветграді в XIX - початку XX ст. (на прикладі сім'ї купців Войнових) // Наукові записки Кіровоградського державного педагогічного університету імені Володимира Винниченка. Серія: історичні науки. 2012. Вип. 15. С. 295-307; Шепель Ф. Визнаю себе винним у тому, що був купцем другої гільдії // Кіровоградський краєзнавчий вісник. 2008. № 2. С. 31-36. 7 Даниленко Л. Династія Харитоненків. Суми: Слобожанщина, 2003; Донік О. Благодійність в Україні (XIX - початок XX ст.) // Український історичний журнал. 2005. № 4. С. 159-177; Ковалинский В. Меценаты Киева. Киев: Кий, 1998.

8 Полное собрание законов Российской империи с 1649 г. Типография II Отделения Собственно Его Императорского Величества Канцелярии. 1830. Т. XXII. С. 358

9 Державний архів Миколаївської області (ДАМО). Ф. 216. Оп. 1 Спр. 2580. 
тополі», згідно якого ті з них, що мали нерухоме майно, мали право протягом двох років проживати на території згаданих міст. Цього ж року в Миколаєві проживало купців-євреїв: 1-ї гільдії - 1, 2-ї гільдії - 1, 3-ї гільдії - 21 купець, які оголосили свій капітал на 1830 р. ${ }^{10}$ Купців всіх національностей проживало: 1 гільдії - 1, 2-ї гільдії - 1, 3-ї гільдії - 42. Караїмів: 3-ї гільдії - 311. У 1835 р. в Миколаєві мешкало: купців 1-ї гільдії - 4 особи, 2-ї гільдії - 3, 3-ї гільдії - 6412.

Перш за все купецтво поповнювалося за рахунок успадкування виду діяльності від батька до сина. Коли купецький син оголошував капітал, це означало, що він стає головою родини та бере повноваження батька займатися торгівельною діяльністю. Особливого поширення таке явище у Миколаєві набуло в останній чверті XIX ст. Збереглися документи за 1880 р., коли до купецтва 1-ї гільдії був приписаний «николаевский 2-й гильдии купеческий сын Иосиф Берков Гохберг с женою его Бассею, а из николаевских 2-й гильдии купеческих сыновей» міська управа йо-

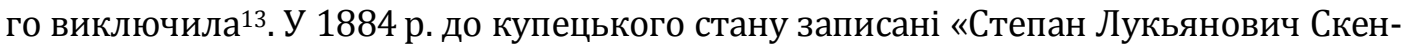
денр с женою Акулиной и их дочерью Мариной»14. У 1885 р. в миколаївські купці записано купецького сина, майбутнього громадського та політичного діяча, благодійника міста М. Авраамова. Згідно діючого законодавства він був записаний разом із родиною, яка складалась із «жены его Анны 26 лет, их сыном Сергеем 7 лет» 15 .

Багато документів присвячено процесу переходу в купецтво представників різних станів міста. Найближчими за соціальним статусом до купецтва були міщани, тому вони частіше від всіх інших станів записувались у купецтво.

Була розроблена спеціальна законодавча процедура щодо запису в купецький стан. Міщанин повинен був написати прохання до Миколаївської міської думи та надати документ про вихід з міщанського стану.

Наприклад, Афанасій Тарасович Бабкін змінював купецькі гільдії та переходив до міщан. 31828 р. протягом п'яти років він був купцем 3-ї гільдії, потім перебував три роки у 1-й гільдії, а в серпні 1835 р. «...магистрат признал меня упадшим, снабдив меня в том документом»16. Декілька років А. Бабкін був міщанином. У 1846 р. подав до міщанського товариства вирок про вихід з міщан. Необхідно було щоб до 3 жовтня 1847 р. товариство надало вирок про перехід «из потомственных мещан в купцы 3-й гильдии»17. А. Бабкин оголосив капітал «со взносом гильдейских и получением свидетельства о торговле» ${ }^{18}$.

Ново-георгіївський купець Д. Кардашев серед документів на вступ у миколаївські купці 2-ї гільдії подав «паспорт Новогеоргиевкой городской думы от 27 апреля... № 335, удостоверение за № 270 не имеющее со стороны мещан общества препятствий на переход его в купечество и ревизские в двух экземплярах сказки»19.

Цікавим є випадок із записом у 1845 р. почесного громадянина міста Брянська в миколаївські купці 1-ї гільдії Андріана Чамова. Згідно з оціночним свідоцтвом «по-

\footnotetext{
10 ДАМО. Ф. 230. Оп. 1. Спр. 19. Арк. 13.

11 Ibid. Арк. 13зв.

12 ДАМО. Ф. 222. Оп. 1. Спр. 34. Арк. 40.

13 ДАМО. Ф. 216. Оп. 1 Спр. 2574. Арк. 2.

14 Ibid. Арк. 5.

15 Ibid. Арк. 9.

16 ДАМО. Ф. 222. Оп. 1. Спр. 101. Арк. 1.

17 Ibid. Арк. 5.

18 Ibid. Арк. 5зв.

19 ДАМО. Ф. 216. Оп. 1 Спр. 196. Арк. 2.
} 
строил в городе Николаеве 1-й части под № 70 два каменных дома с пристройками ценою в 14 тыс. 500 руб.»20. Відповідно до указу Сенату від 7 січня 1838 р. «Про дарування купцям та ремісникам міст Миколаєва та Севастополя пільг щодо сплати гільдійських повинностей», А. Чамов звільнявся від сплати гільдійських зборів протягом десяти років, тому що приїхав із іншої губернії і побудував два будинки в Миколаєві21. Пільгу нарахували від 1 січня 1845 р. до 1 січня 1855 р. «так чтобы он в течение трех лет вносил только городские изменения повинности, а остальные 7 лет взносил... гильдейские пошлины»22. У результаті дозволялося вручити А. Чамову купецьке свідоцтво.

У 1854 р. до купецького стану $з$ міщан перейшли I.Акунін 23 , М. Махотін²4, Д. Гресь 25. Миколаївський міщанин О. Карякін для переходу у 1862 р. у купці 3-ї гільдії надав ревізькі казки у двох екземплярах та оголосив «на сей 1862 г. по Николаеву третьегильдейские и прочие повинности, всего 84 руб. 24 коп. серебром» 26.

У 1845 р. до Миколаївської міської думи направив прохання про зачислення до купецького стану, а саме 3-ї гільдії, міщанин Ф. Авчінніков «для чего взнес с третьегильдийскаго капитала»27. Дума схвалила документ, а в березні 1845 р. Миколаївське міщанське товариство надіслало свою постанову про відбування Ф. Авчинніковим рекрутської повинності: «увольнение его из мещанского сословия представляется ему, Авчинникову, право перечислиться с семейством своим в купечество» 28 , про що Миколаївське міщанське товариство надіслало в березні 1845 p. рапорт до Херсонської казенної палати. До того ж Ф. Авчінніков сплатив «третьегильдийского капитала 66 руб., наземскую повинность на вспомогательный капитал 3 р. 40 коп. и в городовой доход 6 руб. серебром. Всего 81 руб. 40 коп.»²9.

Прохання до зарахування у купецький стан надсилали міщанки. Хоча це явище було набагато рідшим, ніж прохання міщан-чоловіків, є документи, які засвідчують, що у 1853 р. міщанка Є. Спісивцова написала прохання «об увольнении ее с двумя сыновьями Иваном и Николаем из сословия мещан для поступления в Николаевские купцы с выдачею ей увольнительного свидетельства»30. Міське товариство постановило, що на черзі у рекрутській повинності Спісивцови не стоять, податки всі за 1853 р. сплатили, тому можна видати синам свідоцтво про звільнення з міщанського стану. 4 вересня 1853 р. Херсонська казенна палата відправила погодження та наказала виготовити свідоцтво, а до купецького стану зарахувати з 14 січня 1855 р. ${ }^{31}$

Дослідники О. Гуржій та І. Гуржій визначили для київського купецтва, що «купці й міщани самі часто-густо ставали посередниками в процесі переходу людей одно-

\footnotetext{
20 ДАМО. Ф. 222. Оп. 1. Спр. 92. Арк. 3.

21 Полное собрание законов Российской империи с 1649 г. Типография II Отделения Собственно Его Императорского Величества Канцелярии, 1830. Т. XXII. С. 358. С. 9.

22 ДАМО. Ф. 222. Оп. 1. Спр. 92. Арк. 4-4зв.

23 ДАМО. Ф. 222. Оп. 1. Спр. 436.

24 ДАМО. Ф. 222. Оп. 1. Спр. 437.

25 ДАМО. Ф. 222. Оп. 1. Спр. 438.

26 ДАМО. Ф. 216. Оп. 1. Спр. 204. Арк. 1.

27 ДАМО. Ф. 222. Оп. 1. Спр. 93. Арк. 2.

28 Ibid. Арк. 4.

29 ДАМО. Ф. 222. Оп. 1. Спр. 94. Арк. 6.

30 ДАМО. Ф. 222. Оп. 1. Спр. 296. Арк. 3.

31 Ibid. Арк. 13.
} 
го стану до іншого»32. Подібні факти знаходимо і в середовищі миколаївського купецтва. Наприклад, прохання I.Селезньова про надання паспорта міщанину Ф. Сішковуз3.

Серед документів знаходимо прохання та подання про зарахування до купецького стану козаків. Наприклад, звільнений з козацького стану з Полтавської губернії Лохвицького повіту Івахницької волості К. Торопатов надав прохання про зарахування його у миколаївські купці 3-ї гільдії на 1846 р. Він сплатив «следуемые с капитала по 3 гильдии гильдейские подати 66 руб., земской повинности 6 руб., вспомогательного капитала 3 руб. 40 коп., в пользу города 6 руб., всего 81 руб. 40 коп.»34, надіслали з Полтавського повіту рапорт з козачим свідоцтвом про звільнення. До того протягом 15 років К. Торопатов мав місце проживання згідно паспортів у Миколаєві ${ }^{35}$.

До купецького стану залучалися деякі представники селянства. У 1852 р. прохання з цього питання написав селянин Ковенської губернії Тельшевського повіту Е. Краузе. Він представив допоміжний капітал у 15 руб. 15 коп. сріблом і просив відіслати в «Тельшевскую окружную управу» ${ }^{36}$. Миколаївська міська дума видала постанову про отримання цієї суми ${ }^{37}$, у результаті чого 1 травня 1853 р. складено документ про переведення ${ }^{38}$. Проте у 1856 р. йому це заборонила робити Миколаївська міська дума, посилаючись на те, що він вніс додатковий капітал замість необхідної суми ${ }^{39}$.

Проте згідно відношення Миколаївського військового губернатора № 2026 від 18 вересня 1856 р. Е. Краузе сплатив «недостающее количество денег поданого числа представленным» у сумі 25 руб.40 Таким чином, Е. Краузе зарахували до купецтва 3-ї гільдії.

Із селян маємо приклад «...вольноотпущенного из крестьянства по желанию причислиться в Николаевское купечество Ивана Борисова Кочкина»41. Останній довів свою належність до православної віри, надіславши рапорти в Херсонську казенну палату про те, що «свидетельство благочинным протоиереем Единоверческой старообрядческой рождества богородичной церкви Константином... что Кочкин с семейством в исповеди и причастии... ежегодно бывает» ${ }^{42}$. Також він показав склад родини: «он, Иван Кочкин, 53 г., его жена Акулина, 51 г.43, сестрою его, Марьею 56 л., братом его Петром, 40 лет, женою Авдотьею, 37 лет, Петра сыновьями Михаилом 12 лет, Дмитрием 10, приемышем Азаровым 28, женою его Матроною, $28 »^{44}$. Йому були призначені повинності 83 руб. 41 коп. сріблом, які він сплатив 7 грудня. У 1859 р. І. Кочкін просився записати його з 2-ї гільдії до 3-ї45.

\footnotetext{
32 Гуржій О., Гуржій I. Купецтво Києва та Київщини XVII-XIX ст.... С. 68.

33 ДАМО. Ф. 222. Оп. 1. Спр. 61. Арк. 54.

34 ДАМО. Ф. 222. Оп. 1. Спр. 97. Арк. 1-1зв.

35 Ibid. Арк. 3.

36 ДАМО. Ф. 222. Оп. 1. Спр. 161. Арк. 1зв.

37 Ibid. Арк. 2.

38 Ibid. Арк. 13.

39 Ibid. Арк. 18.

40 Ibid. Арк. 12.

41 ДАМО. Ф. 222. Оп. 1. Спр. 326. Арк. 1.

42 Ibid. Арк. 3-Ззв.

43 Ibid. Арк. 5.

44 Ibid. Арк. 5зв.

45 Ibid. Арк. 11.
} 
До купецького стану зараховувались селяни однодвірці. Так, однодворець Київської губернії 6 грудня 1856 р. просив зарахувати його у миколаївські купці 3-ї гільдії. При цьому він надав свідоцтво про звільнення з однодвірців ${ }^{46}$. У свідоцтві, виданому однодвірським товариством, зазначено, що К. Рогацький звільнений з однодвірців у 1854 р.47 4 листопада 1859 р. він був зарахований до купецького стану48.

У 1885 р. «отношение городской управы от 19 февраля № 653» до миколаївського купецтва 2-ї гільдії зарахований селянин Олексій Мінаєв, закріплений за Корениською волостю віком «29 лет, с женою Агафьею 28 лет, сыновьями Алексеем 6 лет и Андреем 3 лет» ${ }^{49}$.

Траплялися випадки, коли до купецтва потрапляли військові чини, як це сталося у 1885 р. з відставним унтер-офіцером Василем Павловичем Гордєєвим і його дружиною Параскою50.

Документом, що посвідчував особу купця при пересуванні у межах Російської імперії, був паспорт. У Миколаєві паспорти представникам купецького стану видавала міська дума. 13 грудня 1838 р. Миколаївський 3-ї гільдії купець М. Павлусенко надіслав до Миколаївської міської думи прохання видати паспорт «на свобоный проезд во все российские города» ${ }^{51} .19$ грудня купці 3-ї гільдії П. Вербицький ${ }^{22}$ i Т. Колесніков 53 надіслали аналогічне прохання. Однорічний паспорт просили для своїх синів купці 1-ї гільдії М. Бухтєєв 54 і 3-ї гільдії П. Діковський 55.

Річний паспорт купця на дозвіл торгівлі - це був аркуш паперу приблизно А5 формату. У ньому зазначався номер запису в спеціальній книзі, описувався зріст, вік і зовнішність. У зовнішності зверталася увага на такі показники: волосся, брови, очі, підборіддя, обличчя 56.

У Держархіві Миколаївської області серед документів, що належать купцям, знаходяться прохання на видачу закордонних паспортів їх родичам. 7 вересня 1862 р. з Одеси на ім'я губернатора надійшла телеграма із запитанням: «можно ли выдать заграничный паспорт племянницы Николаевской купчихи Булавинцевой Елизавете» 57 , на яку була надана позитивна відповідь.

Також для вільного пересування територією Російської імперії купцям видавалися свідоцтва. Наприклад, 23 серпня 1838 р. 1-ї гільдії купецький син К. Соболєв просив «снабдить меня свидетельством на свободный проезд в Киев сроком на 28 дней»58. Збереглось свідоцтво, видане 1846 р. купцю 1-ї гільдії М. Шевченку59.

Купець П. Анікєєв планував передати доньку Євгенію «попечительнице Одесского благородного девичьего института» ${ }^{60}$, для чого просив видати свідоцтво на ім'я доньки.

\footnotetext{
46 ДАМО. Ф. 222. Оп. 1. Спр. 411. Арк. 1.

47 ДАМО. Ф. 222. Оп. 1. Спр. 411. Арк. 2.

48 Ibid. Арк. 7.

${ }^{49}$ ДАМО. Ф. 216. Оп. 1 Спр. 2574. Арк. 8.

50 Ibid. Арк. 9.

51 ДАМО. Ф. 222. Оп. 1. Спр. 64. Арк. 22.

52 Ibid. Арк. 23.

53 Ibid. Арк. 25.

54 ДАМО. Ф. 222. Оп. 1. Спр. 60. Арк. 4.

55 Ibid. Арк. 25.

56 ДАМО. Ф. 222. Оп. 1. Спр. 64. Арк. 34зв.

57 ДАМО. Ф. 230. Оп. 1. Спр. 4088. Арк. 1.

58 ДАМО. Ф. 222. Оп. 1 Спр. 62. Арк. 70.

59 ДАМО. Ф. 222. Оп. 1. Спр. 96. Арк. 13зв.

60 ДАМО. Ф. 222. Оп. 1. Спр. 60. Арк. 116.
} 
Купецтво Миколаєва також поповнювалося за рахунок переїзду осіб з інших міст, перш за все, купців. Наприклад, одеський купець I. Куперман ${ }^{61}$, тираспольський - А. Шварц.62

Купець 2-ї гільдії Д. Ляшковський перейшов у миколаївське купецтво із ніжинських міщан 63 . Він вніс у 1847 р. в казну і на користь міських повинностей оплату, «для чего прилагаю... крепость на купленные мною фундаментом заложенные два дома» 64 . На 1848 р. оголосив свій капітал і був зарахований до купців 3-ї гільдії лубенський міщанин Ф. Яценко 65.

У 1860 р. очаківський купець М. Полікарпов згідно рапорту Миколаївської міської думи № 14 від 14 січня 1860 р. перейшов до миколаївських 3-ї гільдії купців і записав всю родину «жену его Анну Данилову 42 лет, их сыновей Григория 12 лет и Нила 5 лет и дочь Елизавету 6 месяцев»66.

У 1873 р. Новогеоргіївський міщанин Д. Кардашев перейшов до миколаївських купців 2-ї гільдії67. У 1884 р. у миколаївські купці вступили одеський міщани Д. Волков ${ }^{68}$, міщанин містечка Новий двір Мейського повіту А. Остринський ${ }^{69}$, херсонський міщанин А. Сосмійㅁ․ У 1885 р. до 2-ї гільдії миколаївських купців приписано Олександрівського повіту Катеринославської губернії Б. Штейна «с женою Ингою, их сыновьями Иосифом и Юлием и дочерьми Рахилью, Инделью, Нехениею»71.

Були ситуації, коли органи влади забороняли вступати до купецького стану. Наприклад, якщо особа не відбула рекрутську повинність. Подібна ситуація трапилась із таганрозьким міщанином Ф. Пластіним, який у 1855 р. подав документи для вступу у 3-ю гільдію миколаївського купецтва. У 1854 р. він був звільнений із таганрозьких міщан і 16 червня 1854 р. Миколаївська міська дума розглядала капітал у розмірі 88 руб. 50 коп. сріблом ${ }^{72}$. Проте у зв'язку із невчасним відбуванням рекрутської повинності Херсонська казенна палата перенесла входження Ф. Пластіна у купецтво на 1856 p.73 Його брат М. Пластін писав, що «подати за 1856 г. по городу Таганрогу Федор Пластин уплатил за две души... и на рекрутской очереди семейство Пластиных при последующих двух наборах состоять не будет, ибо при первом и втором последующих наборах должны ожидать рекрутской очереди 82 семейства» 74 .

4 березня 1858 р. Херсонське губернське правління надіслало до Миколаївського військового губернатора документ, в якому розкривало причини заборони зарахування М. Бубнова до купецького стану. Зокрема зазначалося про наявність у Спаському магістраті двох позовів від 1857 р. на М. Бубнова про стягнення «...денег скопинским купеческим племянником П. Шамановым 42 руб. 83 коп. и капитан-

61 ДАМО. Ф. 216. Оп. 1. Спр. 2574. Арк. 6.

62 ДАМО. Ф. 216. Оп. 1. Спр. 2574. Арк. 1зв.

63 ДАМО. Ф. 222. Оп. 1. Спр. 93.

64 ДАМО. Ф. 222. Оп. 1. Спр. 106. Арк. 2.

65 ДАМО. Ф. 222. Оп. 1 Спр. 98. Арк. 11.

66 ДАМО. Ф. 222. Оп. 1. Спр. 634. Арк. 4.

67 ДАМО. Ф. 216. Оп. 1 Спр. 196.

68 ДАМО. Ф. 216. Оп. 1 Спр. 2574. Арк. 4.

69 Ibid. Арк. 8зв.

70 Ibid. Арк. 11.

71 Ibid. Арк. 12зв.

72 ДАМО. Ф. 222. Оп. 1. Спр. 325. Арк. 5.

73 Ibid. Арк. 7.

74 Ibid. Арк. 16. 
шею А. Зайкиною 402 руб. 85 3/4 коп. Решение по этим судам... взыскать с означенного деньги не приводится в исполнение по первому делу с 1846 г., а по второму делу с 1849 г.»75, тому що він переходить з одного міста до іншого.

Таким чином, миколаївське купецтво не було закритим станом, а поповнювалося за рахунок переходу представників міщан, козаків і селян. Більшість записуваних до купецтва були міщанами, тому що за родом своєї діяльності вони були найближче до купецтва. Рідше миколаївське купецтво поповнювалося за рахунок козаків і селян. Джерелом поповнення миколаївського купецтва, крім міщан, козаків і селян, були купецькі сини та купці з інших міст. Важливим елементом для купців, які виїжджали з міста, була наявність паспорту або свідоцтва.

Дана тема може знайти своє продовження під час дослідження історії купецьких родин Миколаєва, торгівельних зв'язків міста, історії створення та розвитку промислових і торгівельних підприємств у XIX ст.

\section{REFERENCES}

Bezshkurenko, A. (2020). Rozvytok torhivli v misti Yelysavethradi u druhii polovyni XIX - na pochatku XX st. [The development of trade in the city of Yelisavetgrad in the second half of the XIX - early XX centuries]. Zbirnyk naukovykh prats $\Lambda^{\prime} O \Gamma O \Sigma, 2, \quad 131-132 . \quad$ DOI: https://doi.org/10.36074/26.06.2020.v2.49 [in Ukrainian].

Bielikov, Yu. (2003). Kupetstvo Kharkivskoi hubernii (druha polovyna XIX - pochatok XX st.) [Merchants of Kharkiv province (second half of the XIX - early XX centuries)]. (Candidate's thesis). Kharkiv [in Ukrainian].

Danylenko, L. (2003). Dynastiia Kharytonenkiv [Kharitonenko dynasty]. Sumy: Slobozhanshchyna [in Ukrainian].

Donik, O. (2005). Blahodiinist v Ukraini (XIX - pochatok XX st.) [Charity in Ukraine (XIX - early XX centuries)]. Ukrainskyi istorychnyi zhurnal, 4, 159-177 [in Ukrainian].

Donik, 0. (2008). Kupetstvo Ukrainy v imperskomu prostori (XIX st.) [Merchants of Ukraine in the imperial space (XIX century)]. Kyiv: Instytut istorii Ukrainy NAN Ukrainy [in Ukrainian].

Donik, 0. (2004). Rodyna Tereshchenkiv $v$ istorii dobrochynnosti [The Tereshchenko family in the history of charity]. Kyiv: Instytut istorii Ukrainy NAN Ukrainy [in Ukrainian].

Hurzhii, 0. (2004). Deiaki problemy stanovlennia kupetskoho stanu v Ukraini [Some problems of the formation of the merchant class in Ukraine]. Kyiv: Instytut istorii Ukrainy NAN Ukrainy [in Ukrainian].

Hurzhii, O. \& Hurzhii, I. (2013). Kupetstvo Kyieva ta Kyivshchyny XVII - XIX st. [Merchants of Kyiv and Kyiv region of the XVII - XIX centuries]. Kyiv: Instytut istorii Ukrainy NAN Ukrainy [in Ukrainian].

Hurzhii, 0. (2004). Kupetskyi stan na Livoberezhnii i Slobidskii Ukraini v druhii polovyni XVII-XVIII st.: problemy stanovlennia ta rozvytku [Merchant status in the Left Bank and Slobidska Ukraine in the second half of the XVII-XVIII centuries: problems of formation and development]. Ukrainskyi istorychnyi zhurnal, 3, 3-21 [in Ukrainian].

Ihnatieva, T. (2003). Kupetstvo Pravoberezhnoi Ukrainy v kintsi XVIII - pershii polovyni XIX stolittia: sotsialno-etnichnyi aspekt [Merchants of the Right Bank of Ukraine in the late XVIII - first half of the XIX century: socio-ethnic aspect]. Naukovi pratsi Kam'ianets-Podilskoho pedahohichnoho universytetu: Istorychni nauky, 11, 172-179 [in Ukrainian].

Kovalynskyi, V. (1998). Metsenaty Kyeva [Patrons of Kiev]. Kiev: Kyi [in Russian].

Kovalinskii, V. (2003). Semia Tereshchenko [Tereshchenko family]. Kiev: Pressa Ukrainy [in Russian].

Lazanska, T. (1996). Sotsialne pokhodzhennia promyslovoi burzhuazii Ukrainy v XIX st. [The social origin of the industrial bourgeoisie of Ukraine in the XIX century]. Ukrainskyi istorychnyi zhurnal, 2, 6573 [in Ukrainian].

Lazanska, T. (1999). Istoriia pidpryiemnytstva v Ukraini (na materialakh torhovo-promyslovoi statystyky $X I X$ st.) [History of entrepreneurship in Ukraine (on the materials of trade and industrial statistics of the XIX century)]. Kyiv: Instytut istorii Ukrainy NAN Ukrainy [in Ukrainian].

Lazanska, T. (2001). Torhovelni domy Ukrainy na rubezhi dvokh stolit (1892-1914 rr.) [Trading houses of Ukraine at the turn of two centuries (1892-1914)]. Problemy istorii Ukrainy XIX - pochatku XX st., 2, 24-41 [in Ukrainian].

75 ДАМО. Ф. 222. Оп. 1. Спр. 529. Арк. 1. 
Marchenko, 0. \& Saltanova, N. (2012). Osoblyvosti rozvytku kupetstva v Yelysavethradi v XIX pochatku XX st. (na prykladi sim'i kuptsiv Voinovykh) [Features of the development of merchants in Yelisavetgrad in the XIX - early XX centuries (on the example of the family of military merchants)]. Naukovi zapysky Kirovohradskoho derzhavnoho pedahohichnoho universytetu imeni Volodymyra Vynnychenka. Seriia: Istorychni nauky, 15, 295-307 [in Ukrainian].

Saltanova, N. (2011). Kupechestvo Elisavetgrada (istoricheskie ocherki) [Elisavetgrad merchants (historical essays)]. Kirovograd: KIRaCH Ukraina [in Russian].

Shepel, F. (2008). Vyznaiu sebe vynnym u tomu, shcho buv kuptsem druhoi hildii [I plead guilty to being a merchant of the Second Guild]. Kirovohradskyi kraieznavchyi visnyk, 2, 31-36 [in Ukrainian].

\section{Hanna Makushina}

(Odessa State Academy of Civil Engineering and Architecture, Odessa, Ukraine) e-mail: annamakusina1981@gmail.com

ORCID: https://orcid.org/0000-0002-0106-9574

\section{Sources of Merchant Class of Mykolaiv Increase in Number in the $19^{\text {th }}$ Century}

In modern Ukraine, trade plays an important role. Thus, the issue of studying the history of the development of a merchant class as a trade relations carrier in Southern Ukraine is relevant. In general, the merchant class was a unique estate, which put atop not the social status but the fortune, i.e. readiness for active trade. The studying of the merchant class increase in number issue makes it possible to find out from which social strata the new representatives of the merchant class were coming.

The goal of the paper is to study the peculiarities of Mykolaiv city merchant class increase in number during the $19^{\text {th }}$ century.

The objectives of the paper are to study the peculiarities of involving persons in the merchant class, to explain the reasons for the transition of ordinary citizens to the merchants of Mykolaiv, to highlight the peculiarities of submitting documents to the city authorities for registration as the merchant, and to study some cases of passport issuing.

Certain attention is paid to the peculiarities of the increase in number of city merchant class with representatives of other strata during the formation and evolution of a merchant stratum of the city during the $19^{\text {th }}$ century. Particular consideration is given to the role of the ordinary citizens in the formation of the merchant class of Mykolaiv and the specifics of their entry into the stratum. The social status of the persons who went over to Mykolaiv merchants from other cities of the Russian Empire is defined.

Keywords: merchant, merchant's son, ordinary citizens, Mykolaiv City Duma, Mykolaiv 